\title{
DAMPAK PROGRAM DIKLAT BAGI GURU MTs ASPEK PEMBELAJARAN
}

\author{
Yasri \\ Pusdiklat Tenaga Teknis Pendidikan dan Keagamaan \\ Email: yasri3469@yahoo.com
}

\begin{abstract}
Abstrak
Penelitian ini difokuskan pada dua permasalahan, yaitu bagaimana dampak program diklat terhadap penyusunan perencanaan pembelajaran dan proses pembelajaran. Penelitian ini bertujuan untuk mengevaluasi dampak program Diklat Teknis Fungsional Guru Madrasah Tsanawiyah yang diselenggarakan oleh Pusdiklat Teknis Kementerian Agama. Penelitian ini menggunakan metode survei dengan model evaluasi dampak diklat. Teknik pengambilan data dengan cara observasi dan wawancara. Pengolahan data dilakukan dengan teknik deskriptif kuantitatif dan naratif kualitatif. Hasil penelitian ini menunjukan bahwa program diklat berdampak terhadap alumni dalam menyusun perencanaan pembelajaran, khususnya penyusunan kelengkapan administrasi pembelajaran dan mengaitkan antar komponen dalam Rencana Pelaksanaan Pembelajaan, melakukan kegiatan pendahuluan pembelajaran, penguasaan materi pelajaran, pembelajaran yang melibatkan siswa. Namun tidak berdampak terhadap pemilihan dan penggunaan metode, media dan sumber belajar, serta melakuan penutupan pembelajaran.
\end{abstract}

Kata Kunci : Dampak Progam, pendidikan dan Pelatihan, Pembelajaran

\begin{abstract}
This study focused on two problems, namely how the impact of the education and training program on the preparation of lesson plans and learning processes. This study aims to evaluate the impact of the Functional Technical Training Program for Madrasah Tsanawiyah Teachers organized by the Ministry of Religion Technical Training Center. This study uses a survey method with a training impact evaluation model. Data collection techniques utilized observation and interviews. Data processing is done with quantitative descriptive techniques and qualitative narrative. The results of this study indicate that education and training programs have an impact on alumni in preparing lesson plans, specifically the preparation of administrative completeness of learning and linking between components in the lesson Plan, conducting pre learning activities, mastering subject matter, and engaging students in learning. But it does not have an impact on the selection of using methods, media and learning resources, and the closing activities of learning.
\end{abstract}

Keywords: Impact of Program, Education and Training, Learning 


\section{PENDAHULUAN}

A rtikel ini mengungkap dampak program pendidikan dan pelatihan (diklat) yang dilaksanakan oleh Pusat Pendidikan dan Pelatihan Tenaga Teknis Pendidikan dan Keagamaan (Pusdiklat Teknis) terhadap pembelajaran bagi guru Madrasah Tsanawiyah (MTs) selaku alumni peserta diklat dalam aspek pembelajaran. Pembahasan aspek pembelajaran guru yang dimaksud adalah penyusunan perangkat perencanaan pembelajaran dan proses pembelajaran secara klasikal.

Guru sebagai Aparatur Sipil Negara (ASN) dalam melaksanakan tugas dan fungsinya harus didukung oleh kompetensi antara lain pedagogik dan profesional (Permendiknas RI Nomor 16 tahun 2007: bagian B) dan dapat meningkatkan kompetensi tersebut dengan mengikuti diklat (UU RI Nomor 5, 2014: pasal 70), sehingga mampu meningkatkan pengetahuan dan keterampilan. Diklat merupakan salah satu instrumen yang dapat digunakan untuk meningkatkan pembelajaran bagi guru di lembaga pendidikan.

Sebagai lembaga kediklatan, Pusdiklat Teknis bertujuan meningkatkan kompetensi Sumber Daya Manusia (SDM) agar dapat melaksanakan tugas pokok dan fungsi secara profesional. Berdasarkan penelitian pendahuluan melalui wawancara terhadap guru MTs di wilayah DKI Jakarta yang cenderung dalam menyusun perencanaan pembelajaran dan melaksanakan proses pembelajaran di kelas seadanya.

Pusdiklat Teknis secara berkala setiap tahun melakukan evaluasi, baik evaluasi pasca diklat (EPD) maupun evaluasi program diklat, namun belum menyentuh dampak yang ditimbulkan dari kegiatan Diklat di Madrasah. Di sisi lain, Pusdiklat Teknis sebagai lembaga kediklatan seyogyanya melakukan evaluasi secara komprehensif dalam rangka menilai capaian, manfaat dan tujuan program secara intrinsik terhadap suatu program (Ulum, Omer Gokham. 2016). Namun, belum ada upaya untuk melakukan evaluasi secara khusus dan secara maksimal tentang dampak dari pelaksanaan program diklat terhadap pembelajaran bagi guru Madrasah.

Fokus penelitian ini adalah evaluasi dampak program diklat guru MTs terhadap perencanaan dan proses pembelajaran. Sehingga rumusan masalah dalam penelitian ini adalah (1) Bagaimana dampak program diklat dalam penyusunan perangkat perencanaan pembelajaran bagi guru MTs? (2) Bagaimana dampak program diklat dalam proses pembelajaran bagi guru MTs?

Evaluasi program adalah implementasi metode penelitian ilmiah dalam membuat akses merencanakan, melaksanakan, menghasilkan sebuah program dan mengintervensi sosial (Albert and Gilbert, 2009: 473). Tahapan Evaluasi program dimulai dari pengukuran, pengumpulan data, pengolahan data dan dampak untuk membuat kebijakan dalam meningkatkan efektivitas program (Stufflebeam dan Shinkfield, 2007: 434).

Kriteria merupakan aspek penting dalam sebuah Proses evaluasi. Beberapa pakar mengkaitkan kriteria dalam konsep evaluasi dengan nilai sangat berkaitan erat. Beberapa pakar memandang bahwa evaluasi sebagai proses menilai sesuatu berdasarkan kreteria. Kriteria harus ditetapkan sebelum mengambil keputusan atas obyek dengan hasil eveluasi yang dilakukan (Djaali dan 
Mulyono, 2008: 1; Stake, 2004: 4 dan Harshit, 2012).

Menurut Ismail (2012) evaluasi program merupakan proses kontributif dalam pengembangan program pendidikan, pengambilan keputusan keberlanjutan, dan menjelaskan situasi terkini sebuah program melaui proses yang sedang berjalan. Evaluasi program dapat memberikan informasi ketercapaian hasil penilaian dan seberapa besar biaya yang diperlukan serta mengungkapkan penyebab ketidaktercapainya sebuah program (Gibney, et al, 2005 : 29).

Namun perlu disepakati sebuah pemahaman bahwa evaluasi program bukan sebuah kegiatan untuk mengukur kesalahan individu atau kesalahan lembaga yang akhirnya akan berpengaruh terhadap suatu putusan akhir sebuah program (Djudjun, 2008 : 18)

Evaluasi dampak program diperlukan dalam pengambilan keputusan oleh pembuat kebijakan terkait ketidakefektifan sebuah program, membuat intervensi, menilai kelebihan, dan menentukan berbagai program alternatif. Evaluasi dampak program berusaha untuk menentukan hubungan antara program dan perbaikan dalam kesejahteraan populasi sasaran (Khandker, S.R., Koolwal, G.B., Samad, 2010). Evaluasi dampak program bertujuan untuk mengetahui seberapa jauh suatu program dapat memberikan pengaruh kepada sasaran dan diukur berdasar kriteria keberhasilan sebagai indikator ketercapaian sebuah tujuan program (Hamalik, 1990: 67)

Pendidikan dan Pelatihan (Diklat) merupakan sebuah upaya yang direncanakan untuk memper-mudah pembelajaran tentang pengetahuan, keterampilan dan prilaku yang berkaitan dengan pekerjaan bagi guru
(Raymond, et all, 2010: 351). Diklat juga merupakan upaya yang direncanakan oleh suatu lembaga untuk mempermudah pembel-ajaran tentang kompetensikompetensi yang berkaitan dengan tugas pokok dan fungsinya. Kompetensi tersebut meliputi pengetahuan, dan keterampilan yang sangat penting untuk keberhasilan pembelajaran guru (Primajaya, Deni, 2012: 6).

Diklat merupakan sebuah kebutuhan bagi guru untuk memiliki pemahaman yang kuat mengenai tugas dan tanggung jawab untuk memberikan informasi, dan keterampilan kekinian terhadap pengembangan profesionalisme (Elnaga, Amir, Imran., 2013). Diklat yang komprehensif dapat membantu mencapai tujuan lembaga dalam mencapai keunggulan yang kompetitif melalui peningkatan kompetensi pengetahuan, keterampilan, dan sikap (Niazi, 2011: Vol 1 No. 2). Dampak dari diklat merupakan perubahan yang akan diterima dan dilaksanakan dengan antusias, seperti kualitas kerja yang lebih baik, produktivitas, kepuasan kerja lebih, dan lebih sedikit kesalahan (Kirkpatrick and D Kirkpatrick, 2005 : 69).

Afshan, et. all, (2012: Vol 4, No 6), mengatakan bahwa ada empat dampak yang ditimbulkan dari program diklat, antara lain dampak terhadap pembelajaran. Diklat dalam peningkatan kinerja adalah keseluruhan kegiatan untuk, meningkatkan serta mengembang-kan kompetensi kerja, pembelajaran, produktivitas, disiplin, sikap dan etos kerja pada tingkat keterampilan sesuai jenjang dan kualifikasi jabatan dan pekerjaan (Undang Undang No. 13 Tahun 2003 Pasal 1).

Sebuah diklat dianggap penting, jika dapat meningkatkan efisiensi dan efektivitas 
pegawai dan organisasi dalam bentuk pengetahuan, keterampilan, serta sikap, meningkatkan dan mengukuhkan sikap dan pengabdian, menyamakan visi dan pola pikir dalam melaksanakan tugas (Kulkarni, Ms. Pallavi P, 2013: Vol. IV, Issue 2). Diklat memiliki hubungan positif dengan kesadaran dalam pekerjaan, persepsi terhadap kualitas pengawasan dan moral (Roehl, Wesley. S,. Skip Awerdlow, 1999: Vol. 23, No. 2).

Penyelenggaraan diklat di Pusdiklat Teknis dilaksanakan secara klasikal dan dengan waktu tertentu. Diklat merupakan kegiatan pembelajaran dalam upaya peningkatan kompetensi dengan durasi waktu minimal 40 jam pelajaran, dengan lama waktu 45 menit per jam pelajaran (PMA Nomor 4 tahun 2012, pasal 15).

Evaluasi terhadap pembelajaran merupakan penilaian yang terencana sehingga dapat diketahui hasil kinerja guru maupun organisasi (Anwar PM, 2007: 10). Program diklat yang dilaksanakan oleh Pusdiklat Teknis minimal berdampak terhadap pembelajaran guru dalam empat hal, antara lain berdampak terhadap kemampuan menyusun perencanaan pembelajaran, melakukan proses pembelajaran.

Kedua komponen tersebut sesuai dengan tuntutan regulasi (UU RI No. 14 tahun 2005: pasal 20) yang mengatakan bahwa dalam melaksanakan tugas keprofesionalan, guru berkewajiban antara lain merencanakan pembelajaran dan melaksanakan proses pembelajaran yang bermutu. Komponen perencanaan pembelajaran terdiri dari (1) kelengkapan perencanaan pem-belajaran, (2) keterkaitan antar komponen, (3) Pemilihan metode, media, dan sumber belajar, dan (4) menggunakan pendekatan pembelajaran (Permendikbud nomor 22 tahun 2016: 2A). Sedangkan komponen proses pembelajaran terdiri dari: prapembelajaran, penguasaan materi, pendekatan, pemanfaatan sumber/media pembelajaran, penilaian, dan menutup pembelajaran (Permendiknas RI no 16 tahun 2007: table 3). Model evaluasi dampak yang digunakan dalam penelitian ini menggambarkan dua komponen yang akan dievaluasi, yaitu: penyusunan perencanaan pembelajaran dan proses pembelajaran.

Proses evaluasi dilakukan untuk menerapkan kriteria dalam menentukan nilai atau kebermaknaan. Dalam proses evaluasi, evaluator harus mampu melaksanakan kegiatan evaluasi yaitu: melakukan pengukuran atau pengumpulan data, dan membandingkan hasil pengukuran dengan kriteria yang sudah ditentukan.

Dengan hasil pembandingan antara hasil pengukuran dan kriteria yang ada, maka, harus ada kesimpulan bahwa apakah sesuatu program, kegiatan, atau produk itu layak, relevan, efisien, dan efektif atau tidak (Nana Syaodih Sukmadinata. 2012: 128).

Kriteria keberhasilan evaluasi dampak program diklat ini diklasifikasi menjadi 5 kategori, yaitu: sangat baik $(92,00$ $100,00)$, baik $(84,00$ - 91,99), cukup $(76,00,00$ - 83,99), kurang $(68,00$ $75,99)$, sangat kurang (kurang dari 67,99 ) (Pusdiklat Teknis, 2013: 5)

\section{METODE PENELITIAN}

Tujuan penelitian ini adalah untuk memperoleh informasi kegiatan yang dilakukan oleh guru MTs dalam mengimplementasikan hasil diklat dalam menyusunan perencanaan pembelajaran dan 
proses pembelajaran. Pelaksanaan penelitian ini dilakukan di 20 MTs Negeri di lingkup binaan Kantor Kementerian Agama Jakarta Selatan selama 3 bulan dari bulan Oktober sampai dengan Desember 2018 dengan banyak responden penelitian 40 orang terdiri dari atasan dan teman sejawat alumni peserta Diklat di MTs.

Penelitian ini menggunakan metode survei yang digunakan untuk membuat taksiran-taksiran mengenai karakteristik obyek penelitian (Kerlinger, 1998: 661). Sedangkan model penelitian ini menggunakan model evaluasi dampak Diklat (Yasri, 2017) yang dimodifikasi..

Model penelitian evaluasi dampak program diklat dapat dilihat pada gambar 1 berikut ini.

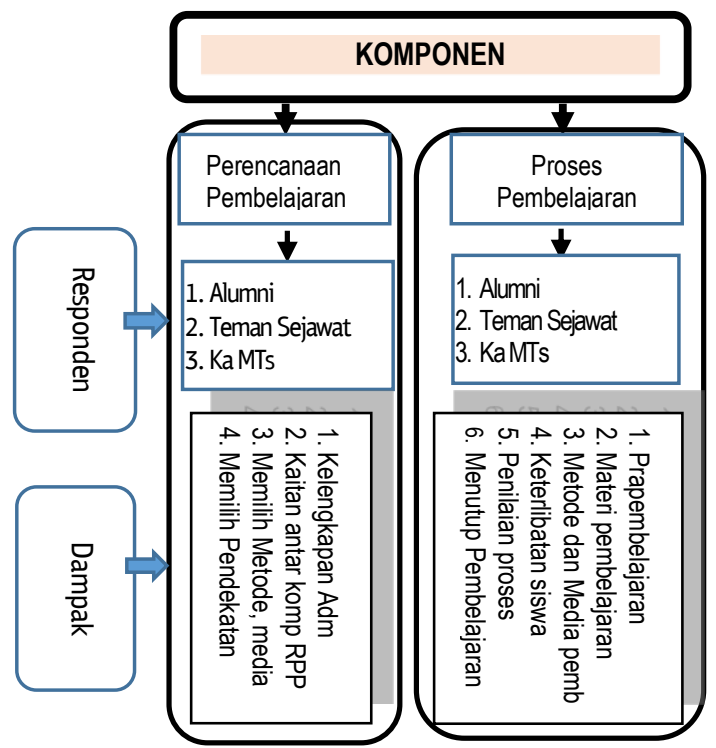

Gambar 1. Desain Evaluasi Dampak Program Diklat Guru MTs

Instrumen yang digunakan dalam mengumpulkan data penelitian ini adalah pedoman observasi dengan Skala Likert sebanyak 37 butir pengamatan, yang terdiri dari 15 butir pengamatan penyusunan perencanaan pembelajaran, 22 butir pengamatan proses pembelajaran dan 2 butir instrumen wawancara. Instrumen dalam bentuk pedoman abservasi digunakan untuk pengambilan data penyusunan perencanaan pembelajaran dan proses pembelajaran.

Sedangkan pedoman wawancara digunakan untuk pengambilan data persepsi tentang pembelajaran alumni dalam melaksanakan tugas di unit kerja yang berkaitan dengan penyusunan perencanaan pembelajaran dan proses pembelajaran.

Teknik pengumpulan data dalam penelitian ini disesuaikan dengan data yang akan diambil, yaitu dengan menggunakan pedoman wawancara dan pedoman observasi.

Untuk mendukung data, akan dilakukan triangulasi, yaitu melakukan wawancara langsung kepada subjek yang berkaitan dengan informasi yang dibutuhkan. Dalam hal ini dilakukan wawancara kepada alumni diklat, atasan dan teman sejawat alumni peserta diklat.

Data hasil penelitian ini dianalisis secara deskriptif kuantitatif dan naratif kualitatif. Data-data hasil observasi dianalisis dengan menggunakan teknik kuantitatif, yaitu berupa rata-rata dan prosentase. Sedangkan data hasil wawancara diolah dengan naratif kualitatif menggunakan sistem koding dan pengelom-pokkan pernyataan yang sejenis.

Langkah-langkah dalam menganalisis data hasil wawancara: (1) Merekapitulasi jawaban dari 2 pertanyaan oleh 6 orang responden, (2) Mengelompokan jawaban/ pernyataan responden berdasarkan pertanyaan, sehingga diperoleh 2 kelompok jawaban, (3) Menganalisis dan mensintesis masing- 


$\begin{array}{lr}\text { masing } & \text { kelompok } \\ \text { pernyataan, } & \text { sehingga } \\ \text { diperoleh } 2 & \text { sintesis } \\ \text { pernyataan } & \text { sebagai } \\ \text { bahan pertimbangan } & \text { memperkuat } \\ \text { untuk rain dalam } & \text { menilaian yang lain } \\ \text { merumuskan kesimpulan } \\ \text { tiap komponen. }\end{array}$

\section{Gambar 2: Hasil Penilaian Perencanan Pembelajaran}

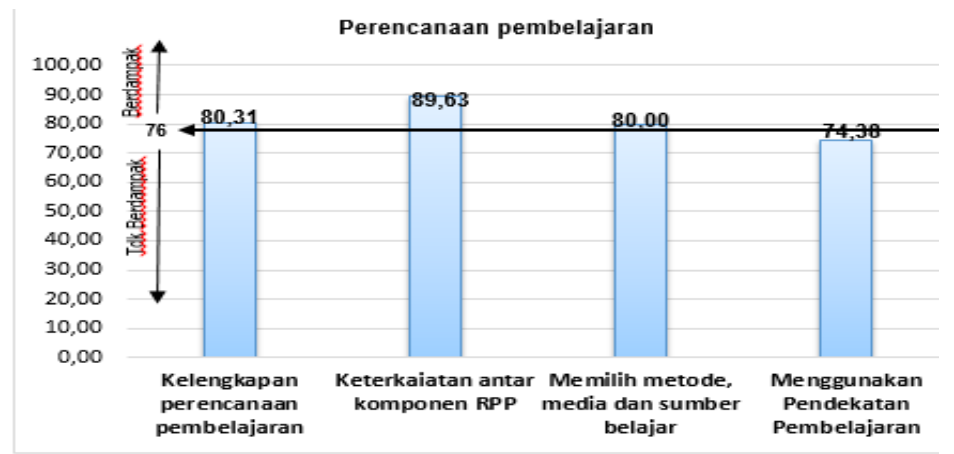

Hasil wawancara dengan tiga orang

\section{TEMUAN DAN PEMBAHASAN}

\section{Temuan}

Hasil penelitian evaluasi dampak program Diklat guru MTs aspek pembelajaran yang diselenggarakan oleh Pusdiklat Teknis ini disajikan dalam dua komponen, yaitu dampak program diklat terhadap: (1) penyusunan perencanaan pembelajaran dan (2) proses pembelajaran. Data hasil pengukuran tiap butir pengamatan dan tiap indikator disajikan dalam bentuk tabel yang berisikan skor, prosentase, nilai tiap butir dan nilai tiap indikator. Sedangkan hasil penelitian dalam bentuk wawancara terbuka disajikan dalam bentuk rangkuman narasi sesuai dengan jawaban responden.

Evaluasi pembelajaran guru sebagai alumni peserta dalam menyusun perencanaan pembelajaran diukur dengan empat indikator, yaitu: kelengkapan perencanaan pembelajaran, menganalisis keterkaitan antar komponen dalam RPP, merumuskan metode/media/sumber belajar dalam RPP, dan menggunakan pendekatan pembelajaran. Data hasil penilaian pembelajaran alumni peserta dikat pada sub kompenen menyusun perencanaan pembelajaran dan tiap indikator dapat dilihat dari gambar 2 . teman sejawat dan tiga orang atasan alumni dalam menyusun perencanaan pembelajaran adalah sebagai berikut: (1) Guru mendapatkan ilmu baru sesuai dengan regulasi dalam menyusun perencanaan pembelajaran, (2) Guru sudah menyusun program tahunan dan program semester, (3) Guru sudah menyusun RPP yang format dan komponennya sesuai dengan panduan, sudah dirumuskan metode pembelajaran dan perencanaan penilaian dan merumuskan pendekatan saintifik dalam rencana pembelajaran, (4) Motivasi pembuatan perencanaan pembelajaran dan merumuskan rancangan metode dan media yang digunakan dengan standar yang sudah ditetapkan masih perlu ditingkatkan.

Evaluasi proses pembelajaran diukur dengan 6 indikator, yaitu: melakukan kegiatan pendahuluan; menguasai materi pelajaran; menggunakan metode, media dan sumber belajar; pembelajaran yang memelihara keterlibatan siswa, melakukan penilaian proses, dan melakukan penutup pembelajaran. Data hasil penilaian pembelajaran alumni peserta dikat pada sub kompenen proses pembelajaran dan tiap indikator dapat dilihat dari gambar 3 berikut: 


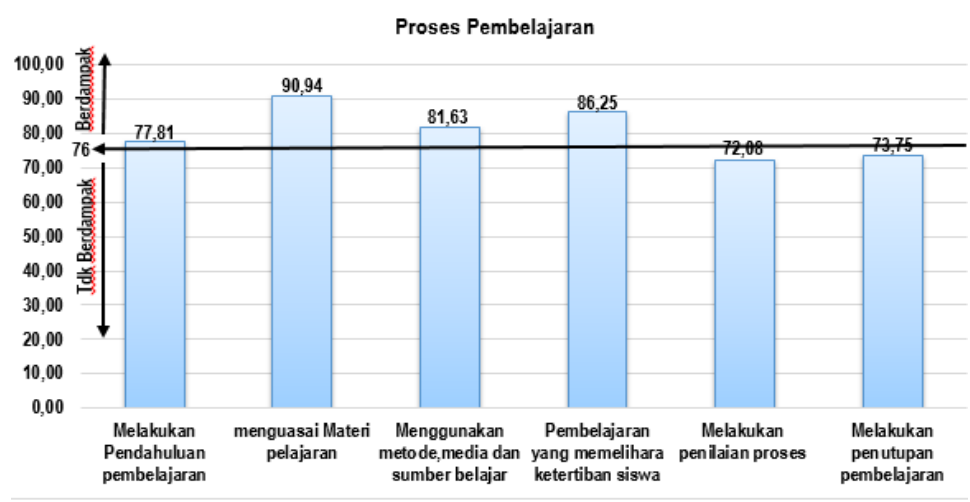

Gambar 3: Hasil Penilaian Proses Pembelajaran

Hasil wawancara tentang proses pembelajaran sebagai berikut: (1) Guru-guru mengajar terlihat lebih baik, antara lain dalam kegiatan pendahuluan, merangsang keingintahuan siswa, dan penguasaan materi pelajaran, (2) Pendekatan pembelajaran menggunakan saintifik, dan menggunakan sumber belajar buku dan LKS, (3) Guru belum maksimal memanfaatkan sumber pembel-ajaran, (4) Siswa sudah aktif dan kondusif dalam keterlibatan pembelajaran. (5) Penilaian proses belum maksimal dilaksanakan, (6) guru melakukan kegiatan penutup rata-rata hanya dengan ucapan salam.

\section{Pembahasan}

Temuan penelitian ini membahas secara sistematis dan menggunakan metode deduktif deskriptif, yaitu mengurai dari halhal yang bersifat khusus ke hal yang bersifat umum. Pembahasan dimulai dari butir pengamatan, indikator, dan komponen evaluasi dampak program diklat. Akhir dari pembahasan ini diperoleh sebuah kesimpulan. Fokus pembahasan temuan ini diklasifikasi menjadi dua dampak program diklat, yaitu dampak terhadap penyusunan perencanaan pembelajaran dan dampak terhadap proses pembelajaran.

\section{a. Penyusunan Perencanaan Pembelajaran}

Pembahasan evaluasi dampak program terhadap penyusunan perencanaan pembelajaran dalam penelitian ini mengacu pada PMA Nomor 165 tahun 2014 tentang kurikulum 2013 mata pelajaran pendidikan agama Islam dan Bahasa Arab pada MTs dan Pemendikbud Nomor 22 tahun 2016 tentang standar proses. Menyusun perencanaan pembelajaran merupakan kemampuan guru dalam menyusun kelengkapan perencanaan pembelajaran, menganalisis keterkaitan antar komponen dalam RPP, merumuskan metode, media, dan sumber belajar dalam RPP dan menggunakan pendekatan pembelajaran.

1) Kelengkapan perencanaan pembelajaran

Kelengkapan

perencanaan pembelajaran bagi guru merupakan instrumen pembelajaran yang harus dimiliki sebagai bagian rangkaian proses pembelajaran.

Ada empat kompetensi penting dalam kelengkapan perencanaan pembelajaran yang perlu dilihat dampaknya setelah guru MTs mengikuti Diklat, yaitu kemampuan membuat program tahunan, program 
semester, komponen RPP yang lengkap dan sistematis, dan instrument penilain proses.

Hasil penilaian kelengkapan perencanaan pembelajaran guru MTs yang pernah mengikuti diklat dalam pembuatan program tahunan terkategori kurang $(75,63)$ dan mencapai $72,5 \%$ guru yang hanya sering menyusun Prota sesuai dengan pedoman yang berlaku. Pembelajaran guru MTs dalam pembuatan prosem juga terkategori kurang $(71,88)$ dan mencapai $45 \%$ guru yang diobservasi hanya pernah membuat Prosem yang lengkap dan sesuai dengan pedoman.

Sedangkan pembuatan RPP dengan lengkap dan sistematis juga terkategori sangat baik $(93,13)$. Namun, hasil pengamatan aspek dokumen instrumen penilaian proses terkategori cukup $(80,63)$. Dengan demikian dapat dinyatakan bahwa penyusunan program tahunan dan program semester mendapat nilai yang paling rendah dan masih kurang atau jarang dilakukan oleh guru. Namun, untuk kompenen RPP sangat lengkap dan disusun secara sistematis sesuai dengan panduan penyusunan RPP. Hal ini disebabkan oleh masih banyak guru yang belum memahami eksistensi program tahunan dan program semester dalam perencanaan pembelajaran.

Secara umum, diperoleh nilai dampak yang ditimbulkan dari keikutsertaan dalam proses kediklatan terhadap indikator kelengkapan perencanaan pembelajaran sebesar 80,31 (Cukup), sehingga dapat dinyatakan bahwa kemampuan guru MTs dalam membuat kelengkapan perencanaan pembelajaran masih terkatogori cukup. Hal ini diakibatkan oleh keberadaan kedua program ini dianggap tidak penting untuk dilengkapi.
2) Mengaitkan antar komponen RPP

Keterampilan guru MTs dalam penyusunan RPP yang mengaitkan antar komponen harus terus ditingkatkan mengingat perkembangan pembelajaran di Madrasah saat ini tidak bisa terhindar oleh cepatnya perubahan kurikulum yang penuh dengan keberagaman. Ada lima pernyataan dalam keterkaitan antar komponen RPP yang dampaknya perlu dilihat, yaitu keterkaitan antara SK/KI dan KD, tujuan pembelajaran dan KD dengan menggunakan kata kerja operasional, indikator pencapaian kompetensi (IPK) diturunkan dari KD, kegiatan pembelajaran (pendahuluan, inti, dan penutup) saling berkaitan.

Dari hasil analisis, lima pernyataan di atas, semuanya berdampak baik, yaitu nilai rata-rata antara 86,88 sampai dengan 91,25 dengan rata-rata nilai dampak 89,63.

3) Memilih metode, media dan sumber belajar

Ada 4 kemampuan dalam memilih metode, media dan sumber belajar yang perlu dilihat dan dianalisis dampaknya setelah guru mengikuti diklat, yaitu pemilihan metode, pemilihan media, pemilihan sumber belajar sesuai dengan karakteristik siswa dan mata pelajaran, dan menerapkan TIK dalam pembelajaran.

Dari empat kemampuan di atas, terdapat dua kemampuan yang kurang berdampak, yaitu: (1) pemilihan metode pembelajaran yang disesuaikan dengan karakteristik siswa dan mata pelajaran dalam RPP bernilai dampak 75,63 (kurang) dan terdapat $75 \%$ guru hanya sering merumuskan metode yang tidak sesuai dengan pedoman, walapupun sesuai dengan karakteristik siswa dan mata pelajaran. (2) Pemilihan sumber belajar bernilai dampak 
kurang $(74,38)$ dan hanya $20 \%$ guru memilih sumber belajar yang sesuai dengan karakteristik siswa dan mata pelajaran secara lengkap.

Sedangkan pemilihan media pembelajaran dan Penerapan TIK dalam pembelajaran berdampak baik, yaitu pemilihan media pembelajaran sebesar 90,63 (baik) dengan 62,5\% guru selalu menyusun dan menerapkan TIK dalam pembelajaran sebesar 88,13 (baik) dengan $57,5 \%$ selalu menyusun.

Berdasarkan analisis tiap butir pengamatan, diperoleh nilai dampak terhadap indikator memilih metode, media dan sumber belajar sebesar 80,00 (cukup). Dengan demikian, dapat dinyatakan bahwa program diklat terhadap kemampuan guru MTs dalam memilih dan merumuskan metode, media dan sumber belajar dalam dokumen RPP cukup berdampak.

\section{4) Menggunakan pendekatan pembelajaran}

Keterampilan alumni peserta diklat (guru) dalam menyusun pendekatan pembelajaran dalam RPP senantiasa harus ditingkatkan mengingat perkembangan cara pembelajaran saat ini di Madrasah sangat cepat mengalami perubahan seiring dengan perubahan kurikulum.

Ada tiga butir perngamatan dalam menilai guru dalam menggunakan pendekatan pembelajaran, yaitu menggunakan pendekatan scientific, Menggunakan model inquiry, discovery, dan project based learning, dan memuat pengembangan sikap, pengetahuan dan keterampilan.

Dari ketiga hasil pengamatan di atas, hanya pendekatan yang menggunakan scientific yang berdampak dalam pembelajaran dengan nilai dampak sebesar 81,88 (cukup).
Sedangkan butir pengamatan lainnya penilaian berdampak kurang, yaitu guru merumuskan penggunaan model inquiry, discovery, dan project based dalam pembelajaran bernilai 71,88 (kurang berdampak), dan Memuat pengembangan sikap, pengetahuan dan keterampilan bernilai 69,38 (kurang berdampak).

Berdasarkan analisis dan pembahasan data peningkatan pembelajaran penyusunan perencanaan pembelajaran alumni peserta diklat yang diukur dengan menggunakan empat indikator dan 16 butir pengamatan dapat dinyatakan bahwa: (1) Terdapat satu indikator pada komponen peningkatan pembelajaran penyusunan perencanaan pembelajaran alumni peserta diklat yang terkategori kurang, yaitu: penggunaan pendekatan dalam pembelajaran $(74,38)$. (2) Terdapat dua indikator pada komponen penyusunan perencanaan pembelajaran alumni peserta diklat yang terkategori baik, yaitu: kelengkapan perencanaan pembelajaran dan memilih model, metode, media dan sumber belajar. (3) terdapat satu indikator terkategori berdampak baik, yaitu keterkaitan antar komponen dalam RPP $(89,63)$.

Kondisi ini didukung oleh hasil wawancara yang mengungkapkan bahwa sudah ada perubahan yang sangat tinggi pada peningkatan penyusunan perencanaan pembelajaran yang ditandai oleh semua guru sudah menyusun perencanaan pembelajaran yang terdiri dari prota, prosem, RPP, penggunaan metode, media pembelajaran serta perencanaan penilaian dengan baik dan sesuai dengan standar proses yang ditetapkan oleh Kementerian Pendidikan dan Kebudayaan. 


\section{b. Dampak Proses Pembelajaran}

Pembahasan temuan dampak program diklat dalam penelitian ini berpedoman pada PMA Nomor 165 tahun 2014 tentang kurikulum mata pelajaran pendidikan agama Islam dan Bahasa Arab pada Madrasah dan Permendikbud Nomor 22 tahun 2016 tentang standar proses.

Proses pembelajaran merupakan kemampuan guru selaku alumni peserta diklat dalam melakukan kegiatan pendahuluan dalam pembelajaran, menguasai materi pelajaran, menerapkan pendekatan/strategi pembelajaran, kegiatan memanfaatkan media, dan sumber belajar, kegiaan pembelajaran yang memicu dan memelihara ketertiban peserta didik, melakukan peniliaan proses, dan melakukan penutupan pembelajaran.

1) Melakukan kegiatan pendahuluan

Kemampuan guru selaku alumni peserta diklat dalam melakukan pendahuluan pada kegiatan pembelajaran di kelas senantiasa harus ditingkatkan, karena kegiatan pendahuluan merupakan momen yang paling tepat untuk pemberian informasi awal yang harus dipahami oleh siswa.

Dalam kegiatan pendahuluan, ada dua hal yang perlu dinilai, yaitu mempersiapkan siswa untuk belajar dan melakukan kegiatan apersepsi. Kemampuan guru selaku alumni peserta diklat dalam mempersiapkan siswa untuk belajar dalam kegiatan pendahuluan terkategori kurang $(73,13)$ dan didukung oleh hasil penilaian yang diperoleh, yaitu: $20 \%$ guru yang diobservasi yang selalu mempersiapkan siswa untuk belajar dan 55\% guru yang selalu mempersiapkan siswa untuk belajar.

Sedangkan Kemampuan melakukan kegiatan apersepsi bagi siswa terkategori cukup $(82,50)$ dengan didukung oleh hasil penilaian yang diperoleh, yaitu: $37,5 \%$ guru yang diobservasi selalu melakukan kegiatan apersepsi dan 55\% teramati sering melakukan kegiatan apersepsi.

Berdasarkan pembahasan di atas, diperoleh nilai dampak yang ditimbulkan dari program diklat terhadap kegiatan pendahuluan dalam pembelajaran sebesar 77,81 (cukup).

2) Menguasai materi pelajaran

Penguasaan materi pelajaran guru MTs senantiasa terus ditingkatkan karena merupakan suatu keharusan. Sebab substansi keilmuan yang ditransfer kepada siswa harus utuh sesuai dengan tuntutan Kompetensi Dasar. Ada empat dampak yang perlu dinilai dalam penguasaan materi pelajaran setelah guru mengikuti diklat, yaitu: kemampuan menguasai materi pembelajaran, mengaitkan materi dengan pengetahuan lain yang relevan, kemampuan menyam-paikan materi dengan jelas dan sistematik, dan kemampuan mengaitkan materi dengan realitas kehidupan.

Hasil penilaian penguasaan materi pelajaran siswa, diperoleh bahwa kemampuan guru dalam menunjukkan penguasaan materi pembelajaran terkategori sangat baik (95.00). Hal ini didukung oleh hasil penilaian yang diperoleh, yaitu: $80 \%$ guru yang diobservasi selalu menunjukkan penguasaan materi selama pembelajaran. Kemampuan guru yang lain yang terkategori baik adalah dalam mengaitkan materi dengan pengetahuan lain yang relevan $(87,50)$ dan menyampaikan materi dengan jelas, sesuai dengan hierarki belajar dan karakteristik siswa terkategori $(90,63)$, dan kemampuan guru MTs yang pernah mengikuti diklat dalam mengaitkan materi dengan realitas kehidupan $(90,63)$. 
Berdasarkan analisis, diperoleh nilai dampak yang ditimbulkan dari keikutsertaan dalam proses kediklatan di Pusdiklat Teknis terhadap indikator penguasaan materi pelajaran sebesar 90,94 (baik).

3) Menerapkan pendekatan pembelajaran

Kemampuan guru selaku alumni peserta diklat dalam menerapkan pendekatan pembelajaran di kelas senantiasa harus ditingkatkan, karena pendekatan pembelajaran merupakan cara yang harus dilakukan agar penyampaian materi pembelajaran dalam pemberian informasi keilmuan dapat tercapai.

Dalam penerapan pendekatan pembelajaran, ada lima hal yang perlu dinilai, yaitu pembelajaran sesuai dengan kompetensi, pembelajaran secara runtut, penguasaan kelas, pembelajaran kontekstual, dan pembelajaran yang sesuai dengan alokasi waktu.

Hasil penilaian dampak program diklat terhadap penerapan pendekatan pembelajaran diperoleh bahwa guru dalam melaksanakan pembelajaran yang sesuai dengan kompetensi berdampak baik $(86,25)$. Penguasaan kelas dan pembelajaran yang sesuai dengan alokasi waktu terkategori berdampak cukup $(83,75$ dan 83,75$)$. Sedangkan pembelajaran yang berbasis kintekstual terkategori kurang $(70,00)$ dan pembelajaran secara runtut sangat kurang dilaksanakan.

Secara umum, dampak program diklat terhadap kemampuan guru mengajar dalam menggunakan pendekatan terkategori cukup $(78,02)$

4) Menggunakan metode, media dan sumber belajar

Kemampuan alumni peserta diklat dalam menggunakan metode, media dan sumber belajar senantiasa harus optimal, karena tiga komponen tersebut merupakan faktor pendukung yang turut menentukan keberhasilan proses pembelajaran di kelas.

Sehingga peranan ketiganya sangat menentukan keberhasilan mengajar seorang guru dan mentransfer materi pelajaran kepada siswa.

Metode mengajar yang diterapkan oleh guru selama proses pembelajaran berdasarkan karakteristik materi yang ada di KD dan karakteristik siswa bernilai dampak 76,25 (cukup).

Media yang digunakan oleh guru dalam pembelajaran yang berhubungan langsung dengan muatan materi yang diajarkan selama pembelajaran dilakukan secara efektif bernilai dampk 82,50 (cukup).

Dalam penggunaan sumber belajar, guru lebih dominan menggunakan buku paket selama pembelajaran secara efektif. Kemampuan guru MTs yang pernah mengikuti diklat dalam menggunakan buku paket selama pembelajaran terkategori baik $(91,25)$. Hal ini didukung oleh hasil penilaian yang diperoleh, yaitu: $70 \%$ guru yang diobservasi sering menggunakan buku paket selama pembelajaran secara efektif.

Berdasarkan analisis tiap pengamatan, diperoleh nilai dampak diklat terhadap indikator menggunakan metode, media dan sumber belajar sebesar 81,63 (cukup).

5) Pembelajaran yang melibatkan siswa

Kemampuan mengajar guru yang melibatkan siswa secara aktif senantiasa harus selalu ditingkatkan, karena kurikulum 2013 menjadikan siswa sebagai subyek pembelajaran. Sehingga keterlibatan siswa dalam pembelajaran mampu menumbuhkan partisipasi aktif siswa selama pembelajaran. Bentuk partisipasi siswa, antara lain sikap 
terbuka dan menumbuhkan keceriaan serta antusiasme dalam belajar.

Ada tiga dampak yang dinilai dalam pembelajaran yang melibatkan siswa setelah guru mengikuti diklat, yaitu menumbuhkan partisipasi aktif peserta didik selama pembelajaran, menunjukkan sikap terbuka terhadap respon siswa, dan menumbuhkan keceriaan dan antusisme peserta didik dalam belajar.

Kemampuan guru dalam melibatkan dan menumbuhkan partisipasi aktif siswa selama pembelajaran terkategori baik $(85,00)$. Hal ini didukung oleh hasil penilaian yang diperoleh, yaitu: $52,5 \%$ guru yang diobservasi sering menumbuhkan keterlibatan siswa selama pembelajaran dan $45 \%$ yang selalu menumbuhkan keterlibatan aktif siswa selama pembelajaran.

Selain kemampuan di atas, kemampuan dalam bersikap terbuka terhadap respons siswa juga terkategori baik $(90,63)$. Hal ini didukung oleh hasil penilaian yang diperoleh, yaitu: $67,5 \%$ guru yang diobservasi selalu menunjukkan sikap terbuka terhadap respons siswa.

Sedangkan kemampuan guru dalam menumbuhkan keceriaan dan antusisme siswa dalam belajar terkategori cukup $(83,13)$. Hal ini didukung oleh hasil penilaian yang diperoleh, yaitu: $47,5 \%$ guru yang diobservasi selalu menumbuhkan keceriaan dan antusisme siswa dalam belajar dan $40 \%$ sering menumbuhkan keceriaan dan antusisme siswa dalam belajar.

Berdasarkan analisis pengamatan, diperoleh nilai dampak yang ditimbulkan dari keikutsertaan dalam proses kediklatan terhadap indikator kegiatan pembelajaran yang memicu dan melibatkan siswa sebesar 86,25 (baik).
6) Melakukan penilaian proses selama pembelajaran

Penilaian proses selama pembelajaran berlangsung harus selalu dilakukan dan kemampuan guru harus selalu ditingkatkan. Hal ini disebabkan adanya tuntutan kurikulum 2013 dan sebagai salah satu pemantauan perkembangan belajar siswa dan sebagai refleksi keberhasilan guru dalam menanamkan sikap, pengetahuan, dan keterampilan sesuai dengan indikator pencapaian kompetensi.

Penilaian pemantauan kemajuan belajar siswa selama proses pembelajaran dan penilaian keterampilan yang sesuai dengan IPK terkategori sangat kurang berdampak. Hal ini didukung oleh analisis data yang menunjukkan bahwa nilai dampak pemantauan kemajuan belajar sebesar 62,50 (sangat kurang) dan penilaian keterampilan yag sesuai dengan IPK sebesar 63,75 (sangat kurang).

Kemampuan guru dalam melakukan penilaian pengetahuan sesuai dengan indikator pencapaian kompetensi (IPK) terkategori baik $(90,00)$. Hal ini didukung oleh hasil penilaian yang diperoleh, yaitu: $65 \%$ guru yang diobservasi selalu melakukan penilaian pengetahuan sesuai dengan IPK.

Berdasarkan analisis dan pembahasan, diperoh kategori dampak yang ditimbulkan dari keikutsertaan dalam proses kediklatan terhadap indikator kegiatan melakukan penilaian proses selama pembelajaran, yaitu kurang berdampak $(72,08)$.

7) Kegiatan penutup pembelajaran

Keterampilan guru dalam melakukan kegiatan penutup pembelajaran harus rutin dilakukan dan perlu ditingkatkan. Kegiatan penutup pembelajaran merupakan rangkaian terakhir yang berisikan beberapa hal, antara 
lain: melakukan refleksi, membuat rangkuman, melaksanakan tindak lanjut.

Penilaian kemampuan guru dalam melakukan refleksi dengan melibatkan siswa terkategori cukup $(78,75)$. Hal ini didukung oleh hasil penilaian yang diperoleh, yaitu: $62,5 \%$ guru yang diobservasi sering melakukan refleksi dengan melibatkan siswa dan 27,5\% guru yang selalu melakukan refleksi dengan melibatkan siswa ketika melakukan kegiatan pentutupan pembelajaran.

Kinerja guru dalam membuat rangkuman dengan melibatkan siswa dalam kegiatan penutupan pembelajaran terkategori kurang $(65,63)$. Hal ini didukung oleh hasil penilaian yang diperoleh, yaitu: $55 \%$ guru yang diobservasi hanya sering membuat rangkuman dengan melibatkan siswa dan 37,5 \% guru yang diobservasi hanya pernah membuat rangkuman dengan melibatkan siswa.

Penilaian terhadap guru dalam melaksanakan tindak lanjut dengan memberikan tugas sebagai bagian remidi/pengayaan terkategori cukup $(76,88)$. Hal ini didukung oleh hasil penilaian yang diperoleh, yaitu: hanya $30 \%$ guru yang selalu melaksanakan tindak lanjut dengan memberikan tugas sebagai bagian remidi/pengayaan.

\section{PENUTUP}

\section{Simpulan}

a. Keterampilan guru dalam menyusun perencanaan pembelajaran, khususnya mengaitkan antar komponen dalam RPP berdampak baik. Sedangkan kemampuan dalam penyusunan kelengkapan administrasi pembelajaran, dan memilih metode, media dan sumber belajar berdampak cukup. Sedangkan penggunaan pendekatan dalam pembelajaran berdampak kurang

b. Hasil pengamatan dan penilaian perencanaan pembelajaran terbagi 3 kriteria dampak, yaitu: (1) Berdampak Baik dalam menyusun komponen RPP lengkap dan sistematis, keterkaitan antara SK/KI dan KD, merumuskan tujuan pembelajaran dengan menggunakan kata kerja operasional, penyusunan IPK, penyusunan langkah pembelajaran yang saling terkait, perumusan materi pembelajaran sesuai dengan KD, dan pemilihan media pembelajaran, dan penerapan TIK dalam pembelajaran. (2) Berdampak cukup dalam menyusun dokumen instrumen penilaian dan penggunaan pendekatan scientific dalam pembelajaran.

Kurang Berdampak dalam menyusun program tahunan dan program semester, pemilihan metode pembeajaran, pemilihan sumber belajar, merumuskan model pembelajaran dan pengembangan sikap siswa.

c. Hasil evaluasi proses pembelajaran terbagi empat kategori, yaitu: (1) berdampak sanat baik dalam penguasaan materi pelajaran, (2) berdampak baik dalam mengaitkan materi dengan pengetahun lain dan realitas kehidupan, menyampaikan materi jelas, melaksanakan pembelajaran sesuai tujuan, dan menggunakan buku paket secara efektif. (3) cukup berdampak dalam melakukan apersepsi, pembelajaran sesuai dengan slokasi waktu, menggunakan metode pembelajaran, dan menggunakan media pembelajaran, menumbuhkan keceriaaan dan antusias siswa, melakukan refleksi dan melaksanakan tindak lanjut. (4) 
kurang berdampak dalam fungsional widyaiswara yang memenuhi mempersiapkan siswa untuk belajar, kualifikasi dan kompetensi yang melaksanakan pembelajaran secara dibutuhkan, (2) Meningkatkan daya runtut dan kontekstual, dan membuat dukung anggaran kediklatan yang rangkuman. memadai.

d. Secara umum program diklat guru MTs berdampak baik dalam dalam perencanaan dan kegiatan proses pembelajaran di kelas, sehingga program tersebut layak untuk dilanjutkan.

\section{Rekomendasi}

a. Badan Litbang dan Diklat Kementerian Agama, hendaknya (1) Merekrut tenaga

b. Pusdiklat Teknis, senantiasa: dalam menyusun kurikulum dan bahan ajar diklat guru MTs perlu mengakomodir pembelajaran berbasis aktivitas/praktik dan materi: (1) pendekatan dalam pembelajaran, (2) praktek mengajar, terutama kegiatan pendahuluan dan penutup, (3) praktik penilaian proses selama pembelajaran.

\section{DAFTAR PUSTAKA}

Abdus Sattar Niazi. (2011) Training Development Strategy and Its Role in Organizational Performance. Journal of Public Administration and Governance ISSN 2161-7104,. Vol 1 No. 2.

Afshan Sultan, et. al. (2012) Impact Of Training On Employee Performance: A Study of Telecommunication Sector In Pakistan. Interdisciplinary Journal of Contemporary Research In Business, Vol 4, No 6.

Anwar Prabu Mangkunegara, 2007. Evaluasi Kinerja SDM. Bandung: PT Refika Aditama.

Arikunto, Suharsimi dan Cepi Safruddin AJ, 2014. Evaluasi Program Pendidikan: Pedoman Teoritis Bagi Mahasiswa dan Praktisi Pendidikan. Jakarta: Bumi Aksara

Djaali dan Puji Mulyono. (2008). Pengukuran Dalam Bidang Pendidikan. Jakarta: PT Grasindo.

Elnaga, Amir, Amen Imran. (2013) The Effect of Training on Employee Performance. European Journal of Business and Management, Vol. 5, No. 4.

Farida Yusuf Tayibnapis. (2008) Evaluasi Program dan Instrumen Evaluasi: Untuk Program Pendidikan dan Penelitian. Jakarta: Rineka Cipta.

Fitzpatrick, J.L, Blaine R. Worthen, dan James R. Sanders. (2004) Program Evaluation: Alternative Approaches and Practical Guidelines, Boston: Person Education

Gertler, Paul. J, et. al. (2010) Impact Evaluation in Practice, . Washington: World Bank. 
Gibney, Michael J. et al. (2005) Gizi Kesehatan Masyarakat, terjemahan Andry Hartono. Jakarta: Penerbit Buku Kedokteran EGC

Gronlund, N. E dan Linn, R.L. (1990). Measurement and Evaluation in Teaching. New York: Mac Milan Publishing Company.

Hafeez, Uzma. (2015). Impact of Training on Employee Performance, Vol. 6, No. 1.

Hamalik, Oemar, (1990), Evaluasi Kurikulum. Bandung: Rosdakarya

Harshit Topno. (2012) Evaluation of Training and Development: An Analysis of Various Models. IOSR Jornal of Business and management ISSN: 2278-487X, Volume 5, Issue 2 , pp 16-17

Ismail Yuksel. (2012). How to Conduct a Qualitative Program Evaluation in the Light of Eisner's Educational Connoisseurship and Criticism Model. Turkish Online Journal of Qualitative Inquiry.

Juanda. (2011) Evaluasi Program Pendidikan dan Pelatihan Prajabatan Golongan III di $B D K$, Disertasi, PPs UNJ.

Kerlinger, Fred N. (1998) Azaz-azaz Penelitian Behavioral. Terjemahan. Yogyakarta: Gajah Mada University Press

Kirkpatrick, D.L and Kirkpatrick, J.D. (2005) Evaluating Training Programs, Third Edition, San Francisco: Berrett-Koehler Publishers Inc.

Khandker, S.R., Koolwal, G.B., Samad, H.A, 2010. Handbook on impact of evaluation.. Washington, DC: The International Bank for Reconstruction and Development.

Khan, Raja Abdul Ghafoor, dkk. (2011) Impact of Training and Development on Organizational Performance. Global Journal of Management and Business Research, Vol. 11, Issue 7.

Kulkarni, Ms. Pallavi P. (2013) Researchers World Journal of Arts, Science \& Commerce, Vol. IV, Issue 2.

Nana Syaodih Sukmadinata., 2012. Metode Penelitian Pendidikan. Bandung: Remaja Rosdakarya.

Noe, R. A, et all., 2010, Manajemen Sumber Daya Manusia, terjemahan. Jakarta: Salemba Empat.

Owen, J.M. (1993). Program Evaluation: Froms and Approaches, Sidney: Soutthwood Press.

Pallavi P Kulkarni. (2010) A Literature Review on Training and Development and Quality of Work Life. Journal of Arts \& Commere. 
Primajaya, Deni. (2012). Pengaruh Motivasi Kerja dan Pelatihan Kerja Terhadap Kinerja Karyawan Pada PT. Pertamina (Persero) UPMS IV Semarang. Jurnal Ilmu Administrasi Bisnis Universitas Diponegoro

Raja Abdul Ghafoor Khan et al. (2011). Impact of Training and Development on Organizational Performance. Global Journal of Management and Business Research Volume 11 Issue 7 Version 1.0

Roberts, A.R and Greene, Gilbert J. (2009). Buku Pintar Pekerja Sosial, terjemahan Juda Damanik dan Cynthia Pattiasina. Jakarta: PT BPK Gunung Mulia.

Roehl, Wesley. S, Skip Awerdlow. (1999) Training and Its Impact on organizational Commitment Among Lodging Employees. Journal of Hospital and Tourism Research, Vol. 23, No. 2.

Spaulding, D.T. (2008) Program Evaluatio in Practice: Core Consepts and Examples for Discussion and Analysis,. San Francisco: Joseey Wiley \& Sons, Inc.,.

Stake, R. E. (2004) Standards-Based \& Responsive Evaluation. California: Sage Publications.

Stufflebeam, D. L. (2003) Internasional Handbook of Education. Boston,. Published by Kluwer Academic Publishers.

Stufflebeam, D.L. dan Anthony J. Shinkfield. (2007). Evaluation: Theory, Models, \& Applications. San Francisco: Jossey-Bass.

Sudjana, D. (2008) Evaluasi Program Pendidikan Luar Sekolah,. Bandung: PT Remaja Rosdakarya.

Ulum, Omer Gokham. (2016). Evaluation of English as A Foreign Language ProgramUsing CIPP (Context, Input, Process adn Product) Model. European Journal of English Language Teaching, Vol. 1, Issue 2 